\title{
Comparative Study of the Professional Attitudes of Prospective Teachers Recruited in Regular and Distance Education Programmes
}

\author{
Uzma Kareem \\ MPhil Students IER, Gomal University DIKhan \\ Dr Asif Jamil \\ Institute of Education \& Research Gomal University Dera Ismail Khan, KPK \\ Email: asifjamil72@hotmail.com \\ Malik Amer Atta \\ Institute of Education \& Research Gomal University Dera Ismail Khan, KPK \\ Mohammad Younis Khan \\ Government Degree College \# 2 Dera Ismail Khan, K.P.K \\ Tahirullah Jan \\ MPhil Student IER, Gomal University DIKhan Khyber Pakhtunkhwa
}

Doi:10.5296/ijld.v2i5.2450ＵRL: http://dx.doi.org/10.5296/ijld.v2i5.2450

\begin{abstract}
Lack of professional attitude in teachers is the burning issue nowadays. The study was done in order to judge whether this difference results due to changed methodology of teaching in distance and regular programmes. The prime focus was on doing a comparative analysis of the professional attitude among the students enrolled in regular and distance) programmes (B.Ed and M.Ed level) in IER, Gomal University and reasons for the differences. Research findings revealed that students enrolled in regular programmes show high levels of professionalism as compared to distance education students. Similarly B.Ed students enrolled in regular programmes showed the highest levels of professional attitude.
\end{abstract}

Keywords: Professional attitude, Distance Education, Regular Education, Prospective Teachers

\section{INTRODUCTION}

Our schools are complex organizations and growing more so all the time. This phenomenon is taking place because of the constant demand for significant, albeit traumatic, reforms in the way schools do things to achieve desired outcomes. Some of these demands emanate from two distinct sources of influence. One is the globalization of the society and the coming of the information age. The other is the changing attitudes of local societal factions towards the institution of education. (John C. Daresh) 
Activities performed for some specific purpose under certain rules recognized by the society can be termed as a profession. Attitude towards profession means a person's feelings, behaviors and commitment towards a certain profession or job. Philip. L. Harriman defines attitude in his book "Handbook of psychological terms" as "readiness to respond in a certain way'. An attitude is an organized and enduring set of beliefs and feelings toward some kind of object or situation and a pre-disposition to behave toward it in a particular way.

Katz and Scotland (1960) suggest that attitude has the following three components.

i). Affective components: These components consist of positive or negative feeling towards an object. Some attitudes are quite irrational and involve little except this effective component e.g. political attitude in their primitive form may be primarily of this character.

ii). Cognitive Component: The word cognitive implies knowing. Hence the cognitive component of an attitude is that aspect based on beliefs or knowledge.

iii). Action Component:. Action component is related to the attitudes in which students and teachers are involved in practical activities.

Attitude cannot be directly observed, but must be inferred from overt behavior both verbal and non verbal. Allport (1954) has written, "The term itself may not be indispensable, but what it stands for?"

Attitudes are different from opinions, values, and beliefs. While attitudes and opinions look similar, opinions differ from attitudes in terms of the degree of generalization and the measurement technique. Opinions are personal reactions against certain events and situations. Attitudes are more general in terms of their effects in an individual's reactions against a group of events at a larger-scale or human communities. People are aware of their opinions, while they may not be aware of their attitudes (Tezbaşaran, 1997, p. 1).

That an individual's attitude towards his/her occupation may affect the end-product and that someone who does not enjoy his/her occupation will not be able to succeed in that occupation, is quite a common opinion in the society (Güven, 1988).

The results of the study conducted by ( Pajares, 1992; Williams and Burden, 1997) show that teachers' attitudes and behaviors influence the students the most.

In an educational setup, teacher is the most important and indispensible constituent (Şişman, 2004,) and achievement of all set educational objectives and desired results is practically not possible without adequate execution of the teaching activities by the teachers (Sünbül, 2001. No matter how well educational or instructional objectives are established, no matter how functional the content of the subject is selected and organized, it is impossible to achieve the desired results from education unless they are performed by teachers with those objectives and insights (Sünbül, 2001, p. 224). For an educational system to achieve its objectives, it is necessary to achieve certain specified objectives within the classrooms, which are the sub-systems of that educational system. The possibility of achieving the specified objectives in the classrooms, however, depends on the activities that take place there. At this point, the major actor is the teacher. Previous studies have revealed that teacher's behaviors in a class setting are closely related with the students' in a variety of aspects. For instance, according to some quotations by Başar (2001: 68) from findings of some research (Thompson, 1993, p.4203), the personal inclination of the teacher is one of the most important variables of students' inclination. There is a positive correlation between teachers' professional concentration and students' modeling that feature of him $/$ her. A positive correlation was observed between teacher's attachment to the subject and that of the students.

The fact that the teachers have positive expectations from the students affects student behaviors. In short, the quality of the teacher's behavior is one important variable which means a lot for the educational system to achieve its objectives. If the teacher is committed and has positive attitude, his performance level increases. Research studies have shown that 
the way a teacher behaves with his students directly effects the students in various ways. Thompson (1993) found that personal competency is directly proportional to the achievement levels of the student. Similarly the attitudes and professionalism of teachers play a crucial role in developing similar qualities within the student teachers. Richardson (1991) narrated that education is nation building activity. The quality of education depends upon ability and efficiency of teachers. If the teachers are well trained, motivated and committed to their profession, learning will be enhanced. Attitudes of teachers play a crucial role in creating a positive atmosphere in the teaching profession. Negative attitude of a teacher may have a negative impact on the teaching process.

A teacher is required to have a higher level of professionalism because of rapidly changing circumstances. The importance of teacher's professional development can't be over emphasized. Hayon (1989) says that the teachers who posses professional and interpersonal skills are more effective in their classrooms in terms of students behavior, attitude and achievement. Smith (1990) has claimed that teacher's personality in the attitudinal sense is a significant factor in teacher's behavior and it has great impact on student's achievement. Attitude of teachers largely depends upon their personal characteristics and disposition both of which are interlinked. Certain behavioral patterns like teacher's intellect, desire to excel, extended professionalism and teaching as a life concern are prerequisite for the teaching profession. Gender also affects the attitude of the teacher (Dodeen, et al, 2003). They found that female teachers have more positive attitude towards teaching profession as compared to male teachers.

Discussing the development of positive attitudes of student teachers Muhammad Hamid Alfendi and Professor Nabi Ahmad Baloch (1979) have stated that student-teaching experience has to be provided under the guidance of experienced teachers, and the main objective of the student teaching programme should be to help the student teacher to teach better. The teacher's intellect, attitude, emotional reactions, various habits and personality effect the students in terms of academic success, personality development, achievement levels etc. (Bloom, 1976; Jeans, 1995; Brooks and Sikes, 1997).

The research literature of the 1960s and early 1970s reported a number of studies that had investigated teacher attitudes and their relation to pupil achievement. Smith (1971) asserted that a teacher's personality in the attitudinal sense is a significant factor in teaching behavior. The research tasks were to identify those elements of personality that affect teaching behavior and to discover how they might be modified in directions to promote pupil growth.

Teacher's attitude toward themselves is evident from the fact that persons who deny or cannot cope with their own emotions are likely to be incapable of respecting and coping with the feelings of others. If teachers are to understand and sympathize with their student feelings, they must recognize and understand their own feelings. Many colleges are responding to this need by including counseling session reflective thinking, and awareness experiences as part of their teacher education programs. These experiences emphasize introspection, self-evaluation, and feedback from other participants. The goal is to help perspective teachers learn more about themselves, their attitudes and how other perceive them.

Teacher training institutions are in moral sense man-makers. Therefore awareness about attitudes becomes vital. Unlike intelligence, the attitude concept has escaped the nature-nurture controversy. All seem to agree that attitudes are not innate, but learned.

Ahmet Güneyli A, Canan Aslanb (2009) conducted a research, The Evaluation of Turkish prospective teachers' attitudes towards teaching. It was observed that a majority of prospective teachers $(61.8 \%$ ) have a positive attitude towards their profession, female students have a more positive attitude when compared to male students. 
Üstuner Demirtas, Comert (2009) conducted a study, The Attitudes of Prospective Teachers towards the Profession of Teaching which aimed to determine whether the prospective teachers' attitudes towards the profession of teaching differ according to gender, socio economic back ground, order of preference of profession, intrinsic/extrinsic motivation. It was found that female prospective teachers, students coming from middle socio economical conditions, students preferring the teaching profession above most other professions and the ones who have intrinsic motives to adopt teaching as a profession were the ones that possessed high levels of positive attitude towards teaching.

\section{Distance Learning}

One way which governments have tried to expand educational opportunities to as many people as possible while keeping down costs is through distance-learning. For those too far away from schools or universities, too busy helping out at home to attend school on a regular basis, or too poor to pay tuition, distance learning has proven to be an attractive alternative. Distance education as compared to regular education, is a different process altogether. Distance learning is a field of education that focuses on teaching methods and technology with the aim of delivering teaching, often on an individual basis, to students who are not physically present in a traditional educational setting such as a classroom. It has been described as "a process to create and provide access to learning when the source of information and the learners are separated by time and distance, or both." Web conferencing, videoconferencing, Educational television, Instructional television are used in the distance education process.

One drawback of distance education has been the lack of proper communication between the teacher and the student. Lack of interaction hampers the development of master-pupil relationship. This is one major disadvantage of distance learning. Flipping through voluminous books with no mentor to guide you can be overwhelming for some students. Discussing the development of positive attitudes of student teachers Muhammad Hamid Alfendi and Professor Nabi Ahmad Baloch (1979 P.15) have stated that effective student-teaching experience can only be provided under the guidance of experienced teachers, and the main objective of the teacher training programme is to help the student teacher to teach better.

This study aims to determine the differences in professional attitude of the prospective teachers belonging to both regular and distance teacher training programmes.

\section{METHODS AND MATERIALS}

This study was designed to compare attitude of Regular and Distance Education prospective teachers towards teaching profession. The population of the study comprised of all the MEd and BEd students enrolled in the Institute of Education and Research and Distance Educational Directorate Gomal University DIKhan. A sample of 25 students each from B.Ed regular/Distance and M.Ed regular/Distance programmes were selected using the simple random sampling technique. Thus the total sample consisted of $50 \mathrm{~B}$.Ed students and 50 M.Ed students. Structured questionnaires were used as instrument for data collection which was built on a three point Likert scale ranging from agrees to disagree. The instrument consisted of twenty-five items related to the problem. Cronbach's alpha was used for checking the reliability of the measuring scale which remained as 8.09. The researcher administered the questionnaire with the help of co-researchers. Mean, standard deviation were used as research statistic, the difference between means (calculated through the t-statistic equation) were used for final evaluation and analysis of results. Collected data were entered in the SPSS (statistical package for social sciences) for its statistical analysis. 


\section{THE STUDY ATTEMPTED TO GET ANSWERS TO THE FOLLOWING RESEARCH QUESTIONS:}

1. Is there any difference between the professional attitude of students enrolled in M.Ed regular and distance programme?

2. Does the B.Ed distance show high levels of professional attitude as compared to B.Ed regular students?

3. Do both regular and distance education students of M.Ed possess more positive attitude towards teaching as compared to regular and distance education B.Ed students.

4. Does there exist any disparity among the professional attitudes of the students belonging to regular programmes as compared to the students belonging to distance programmes.

Table 1: Results of t-test showing comparative professional attitudes of students enrolled in of M.Ed regular and M.Ed distance programmes.

\begin{tabular}{|l|l|l|l|l|l|l|}
\hline Group & $\begin{array}{l}\text { No of } \\
\text { Student }\end{array}$ & Mean & S.D & Sp & t.cal & t.tab \\
\hline $\begin{array}{l}\text { M.Ed } \\
\text { Regular }\end{array}$ & 25 & 2.248 & 11.012 & 10.85 & 0.020 & \pm 1.671 \\
\cline { 1 - 1 } $\begin{array}{l}\text { M.Ed } \\
\text { Distance }\end{array}$ & 25 & 2.185 & 10.707 & & & \\
\hline
\end{tabular}

Independent sampled t-test was applied to compare the attitudes of students enrolled in of B.Ed regular and B.Ed distance students towards teaching profession. With reference to the difference in attitudes of students enrolled in B.Ed regular and B.Ed distance programmes, the mean value of B.Ed regular and B.Ed distance students are 2.264, 2.166 where as standard deviations of 11.09 and 10.613 revealed that B.Ed regular students possess high levels of professionalism as compared to the students enrolled in B.Ed distance programme. The calculated t-value is -2.961 , which is more than the tabulated value hence statistical analysis of data shows that there exists considerable difference among the professional attitude of students enrolled in M.Ed regular and M.Ed distance programmes.

Table 2: Results of t-test showing comparative professional attitudes of students enrolled in of B.Ed regular and B.Ed distance programmes.

\begin{tabular}{|l|l|l|l|l|l|}
\hline Group & No of Student & Mean & S.D & t.cal & t.tab \\
\hline B.Ed Regular & 25 & 2.264 & 11.091 & & \\
\cline { 1 - 1 } $\begin{array}{l}\text { B.Ed } \\
\text { Distance }\end{array}$ & 25 & 2.166 & 10.613 & -2.961 & \pm 1.671 \\
\hline
\end{tabular}

Independent sampled t-test was applied to compare the attitudes of students enrolled in of M.Ed regular and M.Ed distance students towards teaching profession. With reference to the difference in attitudes of students enrolled in M.Ed regular and M.Ed distance programmes, the mean value of M.Ed regular and M.Ed distance students are2.248 and 2.185 where as standard deviations of 11.012 adn10.707 revealed that M.Ed regular students possess high levels of professionalism as compared to the students enrolled in B.Ed distance programme. The calculated $t$. value is -2.961 , which is more than the tabulated value hence statistical analysis of data shows that B.Ed distance students do not show high levels of professional attitude as compared to B.Ed regular students. 
Table 3: Results of t-test showing comparative professional attitude of students enrolled in B.Ed (regular and distance) and M.Ed (regular and distance) programmes

\begin{tabular}{|l|l|l|l|l|l|}
\hline Group & No. of Student & Mean & S.D & t.cal & t.tab \\
\hline M.Ed Regular & 25 & 2.248 & 11.012 & \multirow{2}{*}{0.020} & \pm 1.671 \\
\hline M.Ed Distance & 25 & 2.185 & 10.707 & & \\
\hline B.Ed Regular & 25 & 2.264 & 11.091 & \multirow{2}{*}{-2.961} & \pm 1.671 \\
\hline B.Ed Distance & 25 & 2.166 & 10.613 & & \\
\hline
\end{tabular}

Independent sample t-test was applied to test the hypothetical assumption made by the researcher. The results of t-test are given below in table-3 According to these results mean scores of B.Ed (regular as well distance) students remained 2.264 and 2.166 respectively. The mean scores of M.Ed regular and distance) students was found as 2.248 and 2.185 respective for both the sampled groups. The calculated t-value i.e. 0.020 was found as greater than that of the tabulated $\mathrm{t}-\mathrm{value}$ for MEd regular and distance education students whereas the calculated t-value for BEd regular and distance education students found as -2.961 remained smaller than that of the tabulated value. The test results indicate a difference of attitude among BEd and MEd students showing a more positive attitude of the senior students than the BEd regular and distance education students

Table 4: Showing the differences in professional attitude of students enrolled in regular programmes (M.Ed and B.Ed) and distance programmes (M.Ed and B.Ed)

\begin{tabular}{|l|l|l|l|l|l|}
\hline Group & No. of Student & Mean & S.D & t.cal & t.tab \\
\hline M.Ed Regular & 25 & 2.248 & 11.012 & \multirow{2}{*}{0.031} & \multirow{2}{*}{ \pm 1.671} \\
\hline B.Ed Regular & 25 & 2.264 & 11.091 & & \\
\hline M.Ed Distance & 25 & 2.185 & 10.707 & \multirow{2}{*}{-2.712} & \pm 1.671 \\
\hline B.Ed Distance & 25 & 2.166 & 10.613 & & \\
\hline
\end{tabular}

Comparison of the professional attitude of students belonging to the regular and distance programmes is shown in table 4. According to these results mean scores of students enrolled in regular programme (M.Ed and B.Ed) was calculated as 2.248 and 2.264 respectively for MEd and BEd students, whereas mean scores of students enrolled in distance education MEd and BEd programme were recorded as 2.185 and 1.166 for both the sampled groups of population. The calculated t-value remained as 0.031 and -2.712 respectively for regular and distance education students, which shows a great deal of difference in the professional approach of both regular and distance education students. The results reveal a more positive professional attitude of regular students towards teaching in contrast to the students who are doing their BEd and MEd through distance education programmes.

\section{DISCUSSION}

Analysis of the data reveals wide ranged differences in the attitude levels of the prospective teachers enrolled in various teaching programmes. Looking closely upon the information provided by the respondents it was found that major differences can be seen in the attitudes of the prospective teachers enrolled in regular and distance programmes. These differences, 
apart from other factors, are mainly due to the fact that both these programmes are run under two totally different procedures. Main point to be considered in this respect is:

- Regular Teacher Training Programmes have the support of a well developed infrastructure behind them. They provide teaching environment, teaching facilities, as well as latest teaching technologies all of which combine to create an environment which helps in developing a professional mindset of the students. Distance Teacher training Programme is a relatively new concept and many educational experts still consider to be passing through the gestation period in our country. It fails to provide a systematic, pre-planned, and well organized teaching programme to the students.

- This type of programmes is designed for the benefit of that student who, due to any reason, cannot find time and resources to attend regular programmes. Distance education, however, does not necessarily mean that there should be a lack of communication and distance between the course supervisor and the students. Provision of mere theoretical knowledge does not provide proper environment to impart professional skills within the students. Constant teacher-student interaction, professional guidance, development of social skills through interaction with fellow students plays a very important role in developing a professional mindset of the students.

- Distance education caters for a considerable number of students every year and its contribution cannot be ignored in any way. However, a lot can be said about the effectiveness of these programmes. The main reason being the fact that these programmes, are not run on professional grounds. Lack of proper planning, implementation and execution of the programmes, lack of use of latest technologies and non-professional attitude of the course supervisors, and lack of inter action among the students, with the course supervisor and even with the students enrolled in regular programmes all combine to create a disaster recipe for the students.

These results of this research second the idea given by Smith (1971) that the personality of the teacher and teachers-student interaction are the main factors that create a positive thinking attitude in the students. The students belonging to distance education programmes lack proper inter- action with the teachers and therefore a major lapse arises in the process of development of proper professional attitude in them. One-on-one interaction of the distance education students with their supervisors, on regular basis, has to be arranged so that it helps in changing the prevailing lethargic attitude and lack of professionalism in the students. They should be involved in workshops, seminar and meetings so that a positive rapport is developed not only among the students but also with the supervisors of the programme which ultimately results in developing high levels of professional attitudes in the teachers of tomorrow.

\section{REFERENCES}

1. Ahmet Güneyli A, and Canan Aslanb, Evaluation of Turkish prospective teachers' attitudes towards teaching Profession (near east university case) World conference on educational sciences (2009) Procedia social and behavioral sciences 1 (2009) 313-319

2. Allport GW. 1954. The Nature of Prejudice. Reading, MA: Addison-Wesley

3. Anderson D.S., (1974). The Development of student-teachers. A comparative study of professional socialization. Organization for Economic Co-operation and Development.

4. Auxiliary Committee of the Indian Statutory Commission, Review of the growth of Education in British India.

5. Best John W (1977), Research in Education ( $3^{\text {rd }}$ Edition) Prentice-Hall Inc.

6. Bhatti M.A (1987), Secondary Education in Pakistan Perspective Planning National Education Council G 8/4 Islamabad. 
7. Bloom, Benjamin. S, Human characteristics and School Learning, New York, McGraw Hill, 1976

8. Borg R. Walter and Gall (1974) Educational Research ( $3^{\text {rd }}$ Edition) Longman New York.

9. Brooks, Val \& Sikes, Pat. (1997). the Good Mentor Guide - Initial Teacher Education in Secondary Schools. Buckingham UK \& Bristol USA: Open University Press.

10. Cleveland Innes, (2010) An Introduction to Distance Education: Understanding Teaching and Learning.. Taylor and Francis

11. Deobold B.Van Dalen, P. (1973). Understanding Educational Research: An Introduction, McGraw Hill,Inc.

12. Dodeen, H. A. et al. (2003) Attitude of pre-service teachers towards persons with disabilities: predication for the success of inclusion. College student Journal 37, 4, 6-10, January

13. Dunlop P.William (1985). Teacher's career stages and patterns of attitudes towards teaching behaviour Journal of Education vol.105.

14. Eyl, B. A. (2012, April). An Examination Of Attitudes Towards Women Retrieved from http://www.benguarslan.com

15. Gold hammer Keith (1973), Admission to Teaching. New York, McGraw Hill Company.

16. Harriman. P.L. (1947). Dictionary of Psychology. Philosophical Library. New York.

17. James W. and Marlin, Jr., (1991) Teacher attitudes, and student learning, journal of Economic education.

18. John C. Daresh, professor of educational leadership at the University of Texas at El Paso.

19. Katz, D., \& Stotland E. (1959), A preliminary statement to a theory of attitude structure and change, In S. Koch (Ed.), Psychology: A study of a science (Vol. 3, pp. 423-475), New York: McGraw-Hill

20. M.W. Travers, R. (1969). An Introduction to Educational Research. New York: McMillan Publishing company

21. Pajares, M. F. (1992). Teachers' beliefs and educational research: cleaning up a messy construct. Review of Educational Research, 62(3), 307-333.

22. Sharma S.R (1992). Teacher Education in India Vol-1 Anmol Publications New Delhi.

23. Smith, B. O. (1971). Research in teacher education, Englewood Cliffs: NJ: Prentice Hall, Inc.

24. Sorenson, H. (1964). Psychology in Education. McGraw Hill Book Company

25. Thorndike R.L (1969). Measurement and Evaluation in psychology and education. John Wiley and sons

26. Üstüner Mehmet, Demirtaş Hassan and Cömert Melike, the attitudes of prospective teachers towards the profession of teaching (2009) (the case of Inonu university, faculty of education), Education and science, vol. 34, no 151

27. Williams, M. \& Burden, R.L. (1997), Psychology for Language Teachers: A Social Constructivist Approach. Cambridge: Cambridge University Press 